\title{
The Jamaican Constitution in Litigation of the Covenant on Civil and Political Rights - Repercussions and Resonances
}

\author{
By Margaret DeMerieux
}

The paper firstly analyses the admissibility decisions of the United Nations Human Rights Committee (hereinafter the UNHR Com.) in a number of cases emanating from Jamaica ${ }^{1}$, to assess the impact of the municipal law - in this instance the Constitution of Jamaica - in the 'international proceeding' under the Optional Protocol to the Covenant. Secondly, the leading case of Pratt and Morgan v. The Attorney General of Jamaica ${ }^{2}$ is examined, as a notable example of litigation in which municipal and international proceedings and processes have reacted on each other, to culminate in a (municipal law) decision of far reaching significance for Jamaica and the Commonwealth Caribbean. ${ }^{3}$

State Party Jamaica has the dubious distinction of having the largest number of communications lodged against it before the Human Rights Committee which hears individual complaints under the Optional Protocol to the CCPR. ${ }^{4}$ The authors of the communications have been 'to a man' they are indeed, no women amongst them, "Jamaican citizen[s] currently awaiting execution at St. Catherine's District Prison Jamaica". 5

1 The cases or communications are: Morgan and Pratt, Nos. 210/1986 and 225/1987 (April 16, 1989); Robinson, No. 223/1987 (March 30, 1989); Reid, No. 250/1987 (July, 1990); Kelly, No. 253/1987 (April 8, 1991); Sawyers and McClean, Nos. 226/1987 and 256/1987 (April 11, 1991); Reynolds, No. 289/1987 (April 8, 1991); Henry, No. 230/1987 (November 1, 1991); Little, No. 293/1988 (July 27, 1992); Thomas, No. 272/1988 (March 31, 1992). In these cases the defendant state is Jamaica.

(1993) 4 All E.R. 769. (P.C.)

3 The term Commonwealth Caribbean refers to those states in the Caribbean Sea or with a Caribbean coast, which were formerly possessions of the United Kingdom and which as a consequence are part of the common law system and in addition share much statute law, albeit with variations, derived from the United Kingdom.

At the end of the 45th Session in July 1992 there had been a total of 92 matters lodged, pending or decided against Jamaica, 61 against Canada and 79 against Uruguay. In 1988, Uruguay ranked first, followed by Canada. Uruguay's former position was no doubt the legacy of its period of military dictatorship, whilst the explanation in the case of Canada appears to be 'activism' on the part of the legal profession.

5 The situation was described in an Amnesty International Report, 'Jamaica: The Death Penalty' (1984/1987). In late 1992, a law was enacted for the classification of murders into capital and noncapital. Consequent upon notification to convicted prisoners of their classification, without prior hearing, a system of review was introduced but the whole matter has now, according to information received, been challenged before the courts and being sub-judice, the 'system' is now in effect suspen- 
The communications all involve persons convicted of murder, after a judge and jury trial, which in all cases discussed, has been followed by an unsuccessful appeal to the Jamaican Court of Appeal. This Court has wide powers, frequently used, to order retrials and this has happened in a few of the cases. Additionally, under section 110 of the Jamaican Constitution, an appeal is possible to the Judicial Committee of Her Majesty's Privy Council (hereinafter the Privy Council), which is still the final court of the Commonwealth Caribbean States, with the exception of Guyana. The appeal in criminal matters, however, is only by leave extended either by the Court of Appeal or the Privy Council itself and is only as of right - no leave of the court is needed, where a matter of interpreting the Constitution is involved. The Privy Council is not a reviewer of fact nor does it ordinarily reassess evidence, though this may be necessary and is done in asserting, or as is more often the case, re-asserting some principle of law. ${ }^{6}$

Turning from the criminal proceeding, the Constitution of Jamaica (promulgated on independence in 1962) contains a chapter on Fundamental Rights and Freedoms, familiarly referred to as (and hereinafter) the Bill of Rights, which, being modelled on the European Convention on Fundamental Rights and Freedoms, shares with the CCPR itself, a common 'ancestral' or progenitor document, namely the Universal Declaration of Human Rights. ${ }^{7}$ As a consequence, the Jamaican Bill of Rights, in addition to containing provisions analogous to those of many found in the CCPR, follows the patterns established by its predecessor documents in providing for a cause of action on a alleged breach of any of the rights conferred.

Sec. 25 (1) and (2) of the Constitution, the redress clause of the Bill of Rights, reads as follows:

25 - (1) [I]f any person alleges that any of the provisions of sections 14 to 24 of this Constitution [the Bill of Rights] has been, is being or is likely to be contravened in relation to him, then without prejudice to any other action with respect to the same matter which is lawfully available, that person may apply to the Supreme Court for redress.

(2) The Supreme Court shall have original jurisdiction to hear and determine any application made by any person in pursuance of subsection (1) of this section ...

ded. Forty-seven death row prisoners, however, have had their sentences commuted under the new law.

A good example is the appeals involving problems of identification. Recent cases include Reid and Ors. v. B.; Reece and Ors. v. R. (1989) 37 W.I.R. 346.

7 The drafters of the Jamaica Constitution used the Bill of Rights appearing in the Nigerian Independence Constitution, which was an adaptation of the European Convention. The matter is averted to in the leading case of Hinds and Ors. v. The Queen (1974) 22 W.I.R. 368 at p. 389 (C.A.). 
Provided that the Supreme Court shall not exercise its power under this subsection if it is satisfied that adequate means of redress for the contravention alleged are or have been available to the person concerned under any other law.

\section{A. The Exhaustion Rule and the Domestic Law}

\section{The Action for Breach of Constitutionally Conferred Rights}

The rule of international law, incorporated in the Optional Protocol at Art. 5(2)(b) which most urgently and frequently compels examination of the Jamaican domestic law is the requirement that persons invoking international procedures of redress for alleged violations of an international obligation should first exhaust local or domestic remedies. Art. 5(2)(b) denies the competence of the UNHR Comm. to consider a communication unless it has ascertained that:

The individual has exhausted all available domestic remedies. This shall not be the rule where the application of the remedies is unreasonably prolonged.

In Pratt and Morgan $v$. Jamaica ${ }^{8}$, the applicants claimed before the UNHR Com. of a breach of the fair and speedy trial provisions of Art. 14 of the Covenant and also of Art. 7, which outlaws inhuman or degrading treatment and punishment, because in each case, of a delay of 45 months in the handing down of reasons for the dismissal of their appeal, which they thought was needed in order to apply for leave to appeal to the Privy Council.

The UNHR Com. interpreted section 25 of the Jamaica Constitution (set out above) in the context of Article 5(2)(b) of the Optional Protocol and in so doing became the first 'adjudicating body' of any kind to directly pronounce upon the effect and scope of the section, this issue not having then come before the Jamaican courts. Jamaica, in response to the communication, argued that it was not within the competence of the UNHR Com. to entertain it, domestic remedies not having been exhausted. No proceedings had been brought by the applicants under the Constitution for redress for alleged breach of the right, not to be subjected to inhuman and degrading punishment or treatment ${ }^{9}$ and the relating to the speedy trials ${ }^{10}$. The Committee, focusing on the proviso in section $25(2)$ decided that the

The UNHR Com. found a breach of Art. 14 on a hearing on the merits and was of the view that while the delay complained of would not ordinarily constitute a breach of Art. 7, it was capable of so doing in a capital case.

9 Section 18, which confers the right not to be subject to inhuman and degrading punishment or treatment specifically saves forms of punishment known to the law at the promulgation of the Constitution.

10 Section 20(2) confers the right to "be given a fair hearing within a reasonable time". 
criminal appeal constituted adequate means of redress and could preclude a constitutional motion. As a consequence domestic remedies had in fact been exhausted.

It can be bluntly asserted that the decision was wrong, though plausible, where the section is read in a vacuum. ${ }^{11}$ No court of the domestic system had ever urged this interpretation not having addressed the matter directly. In a number of cases, however, constitutional motions had been brought without any attempt to exhaust the criminal proceedings and no objection had been taken thereto under the proviso. Even more significantly, in at least one case, the one case in the domestic law which dominates in arguments before the Committee, namely Riley, the conclusion of the criminal proceedings, the abandonment or dismissal of appeals to the Privy Council, had not obstructed the constitutional proceeding under section 25, which in its turn reached the Privy Council. ${ }^{12}$

The foregoing notwithstanding, section 25(2) in particular does require more examination. Firstly, it has always been the 'suspicion' of the writer, that the proviso to section 25(2) was a bizarre attempt to write into the domestic law a rule paralleling that of the exhaustion of domestic remedies in international law, in which, in substitution for 'domestic remedies', remedies other than that given under the Bill of Rights in section 25, had to be exhausted. ${ }^{13}$ The principal objection to the proviso is, and continues to be its potential for robbing the individual of the constitutional action (and redress) - as is in fact illustrated by the Committee's interpretation of the proviso. ${ }^{14}$

The Committee's sruggles with domestic law have been the subject of comment by officials of the Communications section of the Human Rights Centre. Marcus Schmidt has said, "[T]he Committee sometimes swims [sic] in the formulation of its decisions and is liable to adopt decisions which, upon close scrutiny, display elements of inconsistency". From "Due Process and the Right to Life", paper presented at the Interrights Seminar, London, February 1989.

12

Riley and Others v. Attorney-General (Jamaica). [1983] 1 All E.R. 719. The Privy Council decided by a majority that execution after prolonged delay and a reasonable expectation that sentence of death would be commuted to life imprisonment, did not infringe the Jamaican punishments clause. The majority effectively responded as though the argument before it was that capital punishment was an inhuman and degrading punishment (saved in any event under the Constitution), whereas the focus of the applicants argument was delay and the treatment involved, which a strong and impassioned dissent, thought capable of inf ringing the section. See, Alexis and DeMerieux, 'Inordinately Delayed Hanging - An Inhuman Punishment', 29 Journal of the Indian Law Institute 356-379 (1987).

This proviso to the redress clause (in some states the word 'shall' is replaced with 'may') occurs in all the Bills of Rights of the Commonwealth Caribbean States, with the notable exception of Trinidad and Tobago. See DeMerieux, Fundamental Rights in Commonwealth Caribbean Constitutions, Barbados, 1992.

14

The potential mischief has, however, in the domestic law of the Commonwealth Caribbean states been realized so far only once. No constitutional motion has been struck out on the grounds that alternative proceedings should have been instituted, but in the Barbados case of Harding v. Attorney-General, the Court having heard the constitutional motion and indeed found a breach (in relation to delayed criminal appeal proceedings - a matter. which prominently features in the Jamaican communications to the Committee), denied redress under the Constitution on the grounds that alternative action should have been taken. Unreported decision of the Barbados Supreme Court No. 1485 of 1990 (March 
It is of course logically arguable, that a criminal court of competent jurisdiction can consider a constitutional issue arising from a criminal proceeding, independent of the constitutional action (this would in practice be an appeal court), if only for the practical reason of saving time and resources. Indeed, in one leading case (which later came before the Committee), the constitutional issue was argued on appeal to the Privy Council in criminal proceedings, no doubt as a matter involving the interpretation of the Constitution under section 110(1). ${ }^{15}$ The Committee itself has pointed out in another Jamaica case, that the applicant was complaining to the Privy Council that his trial had been unfair, and that "Court of every State Party should ex officio test whether the lower court proceedings observed all the guarantees of a fair trial", in order to conclude that the constitutional action was no longer available, because this issue had been in effect decided in the criminal hearings. ${ }^{16}$ Nevertheless, the problem created by the proviso is whether and to what extent criminal appeal hearings would in fact treat the issue of a constitutional breach, arising from the trial, as a constitutional issue and be prepared to redress it as such. There have been a number of cases, in which the appeal court has been requested to redress a breach of the Constitution (by rejecting unconstitutionally obtained evidence for example) and has refused, treating the issue as purely, one of the criminal law. ${ }^{17}$

The other problem of treating the criminal proceedings as one in which the constitutional issue should or can be heard, because of the proviso to section 25(2), is that several constitutional issues arising out of criminal matters (and implicating rights parallelling those in the CCPR) are arguably not best suited to courts hearing a criminal appeal. This would for example be the case where it is argued that a specific form of punishment prescribed by the law infringed the punishment and torture, or questions or retroactive penal legislation and double jeopardy - all matters addressed both by the Jamaican Constitution and the Covenant.

Subsequent to Morgan and Pratt, the UNHR Com. regularly applied its interpretation of section 25(2) to bring communications within its competence and regularly requested the State Party to inform it whether or not the Jamaican courts had pronounced on the section, as to its effect on the availability of the action under the Constituency. In the absence of

1991). See too, Davis v. Renford and Ors. (1980) 37 W.I.R. 308 denying redress under the Constitution on the grounds that alternative action should have been taken. Unreported decision of the Barbados Supreme Court No. 1485 of 1990 (March 1991). See too Davis v. Renford and Ors. (1980) 37 W.I.R.

Robinson v. The Queen [1985] 2 All E.R. 594. See infra, discussion of section 110(1) of the Constitution of Jamaica, which gives an appeal to the Privy Council, as of right, in criminal matters, involving questions of the interpretation of the constitution.

17 Henry, supra, note 2 at 7.2 .

Compare, King v. The Queen [1969] A.C. 774 and R.v. Howard, (1970) 16 W.I.R. 67. 
such pronouncement, the Committee's interpretation prevailed so that the domestic remedy was considered exhausted.

But the course of the section 25 interpretation was to take a new twist. The Jamaican authorities decided to execute Morgan and Pratt anyway - and despite findings of violations of the Covenant and a 'recommendation' by the Inter-American Commission for a commutation of sentence. The two gentlemen, eventually, in February 1990 instituted constitutional proceedings alleging violations of section 20(1) of the Constitution relating to delay and the Committee was 'robed' of its interpretation of section 25(2). The constitutional notion could be brought after the criminal proceedings had fully run its course.

In post-admissibilitiy observations, beginning from the 43rd session in November 1991 , the Committee's approach to the exhaustion rule where constitutional proceedings have not been pursued is as follows: Where the facts permit, the Committee will declare that criminal appeal courts had a duty to examine the fairness of the trial. ${ }^{18}$ If then asserts that as legal aid is not available for the constitutional motion, "it is not the author's indigence which absolves him from pursuing Constitutional remedies, but the State Party's unwillingness or inability to provide aid" ${ }^{19}$. The absence of legal aid thus makes the constitutional remedy 'unavailable' for Art. 5(2)(b) purposes. It is not connected to actual lack of means in an author and is increasingly now an assertion. ${ }^{20}$

The Committee has also contended that where, in criminal appeals, the author has claimed to be "a victim of injustice", the fair trial issue is before the court that issue implicating a violation of section 20 of the constitution. In this way, though not actually asserted, the constitutional remedy is in effect exhausted on the dismissal of the criminal appeal. ${ }^{21}$ The argument, though perhaps plausible is nevertheless untenable, where in any event the right to bring the constitutional motion persists.

Wright para. 7.4., Thomas para 10.2; Hibbert para 6.2. The point has been buttressed by reference to "the unreasonably prolonged" proceedings that the pursuit of the constitutional remedy would entail (Henry para. 7.4).

Little para. 7.2. In this case and in Henry, specific fair trail issues were not put before the Privy Council on the criminal appeal. 

in Dispute ${ }^{22}$

In Morgan and Pratt, Jamaica argued that the Committee could not in its admissibility deliberations apply understandings of the 'domestic remedies exhaustion rule', other than that stated in Art. 5(2)(b) of the Optional Protocol which excuses exhaustion where the "application of the remedies is unreasonably prolonged". The Committee's response in this and at least one other of the Jamaican cases has been the proposition: "[That] the local remedies rules does not require resort to appeals that objectively have no prospect of success is a well established principle of international law and of the Committee's jurisprudence" $^{23}$.

The authors had claimed that the delay in the proceedings itself constituted 'cruel, inhuman and degrading treatment' in violation of Art. 7 of the CCPR. Counsel pointed to a decision of the Privy Council, Riley and Ors. v. Attorney-General (Jamaica) ${ }^{24}$, to argue that the point had been authoritatively decided against the authors by that decision, negating the need to exhaust domestic remedies. In fact, the issue in Riley was not that put forward by the authors, that case having decided that to carry out the death sentence after prolonged delay, did not infringe the Jamaican Constitution's analogue of Art. 7, viz., section 17. The argument of Jamaica, that it was open to the authors to claim that Riley had been decided per incuriam, was however rightly rejected by the Committee. ${ }^{25}$ The Committee could then apply the understanding of the exhaustion rule under discussion to conclude that counsel could objectively take the view that a constitutional motion would inevitably fail.

It is to be noticed, however, that though a matter of admissibility, the issue raised is the substantive meaning to be given the contested right and therefore, the very question of the breach of the international obligation. Further, and distinct from the foregoing, it may be easy to conclude in a given case that a domestic remedy will fail, not because of an adverse authoritative decision of a domestic court but simply because the claim has no merit. In Collins, in which the complaint related to the alleged bias of the judge; the evaluation by the judge of the evidence in instructing the jury and an allegation of jury

The Committee's earliest application of the rule occurred in Lovelace v. Canada, No. 24 (1977 (August 14, 1979). Selected Decisions under the Optional Protocol, 10.

23

Morgan and Pratt, para. 12.3.

Supra, note 12.

Ibid., para 12.5. The State Party would have been better advised to argue that the author's claim that delay constituted inhumane and degrading treatment had not been determined by the domestic court. At the same time however, the Committee's further assertion that the dissenters in Riley "did acknowledge that the constitutional remedy was only available where there was no other adequate redress", is incomprehensible, since this was not an issue before the Privy Council. 
tampering by an investigating officer, the author had been advised by leading English counsel that a petition to the Privy Council for leave to appeal in a criminal proceeding would fail, as having little merit. ${ }^{26}$

The Committee having decided that there was no domestic remedy in the form of a criminal appeal to the Privy Council, noted immediately thereafter that "the evaluation of evidence and the summing op of legal issues by the judge was neither arbitrary nor amounted to a denial of justice and the judgment of the Court of Appeal clearly addressed the grounds of an appeal". The Committee concluded from this that the Privy Council petition "would have no prospect of success". ${ }^{27}$

The domestic exhaustion rule then leads to the proposition that a claim which would fail for lack of merit in the domestic law creates a lack of an effective remedy in that law. This, no doubt points to difficulties in aspects of the exhaustion rule itself, and raises wider issues as to its application in international human rights regimes. As one function of the rule in general international law is to be a filter or indeed, barrier, preventing the overwhelming of the international complaints system concerned, its operation should be adapted from its general international law context as necessary to promote that function, in connection with complaints before the Committee. A disturbing feature of the views here considered and once again highlighted in Collins is the misreading of the domestic legislation. Section 110 of the Jamaica Constitution was interpreted in Collins, as it impinged on the existence and hence exhaustion of a domestic remedy - and as just seen as it involved the 'prospect of success' aspect of the domestic remedy rule. Section 110 (as relevant) reads as follows:

(1) An appeal shall lie from decision of the Court of Appeal to Her Majesty in Council as of right in the following cases - [...]

(c) final decisions in any civil, criminal or other proceedings on questions as to the interpretation of this Constitution. (Emphasis added) ${ }^{28}$

It might have been thought abundantly clear that there was no question of needing leave to appeal from any court in the circumstance mentioned at section 110(1)(c), nor yet that it

At para 3.9., it was said: "Leading counsel, the President of the Bar Council (United Kingdom) considers that although there were weaknesses in the evidence against the author during his re-trial as well as in the handling of the defence case, the likelihood of the Judicial Committee [Privy Council] trant[ing] special leave to appeal in respect of those matters would be remote".

At para 7.4. It may be noted also, that where a communication is based on Art. 14(1) claim of an unfair trial on allegations such as figured in Collins, it has been declared inadmissible under Art. 3 of the Optional Protocol, as incompatible with the CCPR. See e.g., A.W. v. Jamaica, No. 290/1988 and D.S. v. Jamaica, No. $304 / 1988$. On the merits, the Committee found no violation of Art. 14(1) and (2) in Collins.

28 Her Majesty in Council is the Judicial Committee of the Privy Council, ordinarily referred to as the Privy Council. 
constitutes a condition for such leave. The sub-section sets out a circumstance in which an appeal lies, as of right and is therefore not subject to a discretion of any kind.

Section $110(2)$ and (3) reads:

(2) An appeal shall lie from decisions of the Court of Appeal to Her Majesty in Council with the leave of the Court of Appeal in following cases -

(a) where in the opinion of the Court of Appeal the question involved in the appeal is one that, by reason of its great general or public importance or otherwise, ought to be submitted to Her Majesty in Council, decisions in any civil proceedings; and

(b) such other cases as may be prescribed by Parliament.

(3) Nothing in this section shall affect any right of Her Majesty to grant special leave to appeal from decisions of the Court of Appeal to Her Majesty in Council in any civil or criminal matter.

The very point of sub-section (3), coming after sub-section (2), is to emphasize that the Privy Council is not bound by sub-section (2) and is free to exercise its discretion to grant leave or not, independent of the terms of the last mentioned sub-section. Moreover, subsection (3), explicitly, does not itself confer powers on the Privy Council, but refers to the pre-existing power to grant special leave to appeal to it. Every petition for leave to appeal to the Privy Council granted by it has previously been refused by the Court of Appeal, so that while (emphasizing once again that the Privy Council is free from sub-section (2)) the Privy Council does not actually apply section 110(2) if it did, it would clearly have a different view of it from that held and applied by the Jamaican Court of Appeal. Quite appropriately, the Privy Council is not required to state reasons for the refusal or grant of a petition and it may thus be possible to conclude that a grant of a petition is premised on the Privy Council's perception that the interests of justice or the existence of an issue require it to hear and determine the matter.

The following is the Committee's interpretation of section 110, in Collins:

In determining whether to grant leave to appeal to the Judicial Committee, the Court of Appeal of Jamaica must generally ascertain under section 110 paragraph 1(c) and 2(a) of the Jamaican Constitution, whether the proceedings involve a question as to the interpretation of the Jamaican Constitution or a question of great general or public importance or otherwise such that it should be submitted to the Privy Council. pursuant to the powers conferred upon it by section 110 , para. 3, the Judicial Committee [of the Privy Council] applies similar considerations. 
The conclusion drawn at the end of the foregoing 'analysis' is inevitably that there is no effective and available remedy, as the petition is bound to or is very likely to fail. The explanation of the 'analysis' of the domestic law as exemplified above can only be that the Committee, consisting in large part of distinguished legal practitioners, academics and the like, declined to read section 110 and relied exclusively on counsel's interpretation. ${ }^{30}$ The alternative, that the Committee read the section and in its own deliberate judgment construed it as in the passage quoted, is not to be contemplated. One may make bold to say that this manner of treating the domestic law is likely to discourage adhence to the Optional Protocol and certainly does not inspire confidence in the Committee. This body could very easily devise means of making itself better able to handle issues from the domestic law.

The admissibility jurisprudence of the cases here considered yield, it is suggested, at least two propositions one for admissibility itself under the Optional Protocol and one for the promotion of the notion of a fair trial on which all the sub-paragraphs of Article 14 is premised.

The first point is to be derived from the refusal to require a judicial remedy to be exhausted for which there is not state-provided legal assistance. This may be seen as an enhancement of the domestic remedies exhaustion rule as derived from general international law and one adapting that rule to the particular character of the litigation, through the international procedures of international human rights. Thus while the Committee's interpretation of Section 25 of the Jamaica Constitution to deny that a domestic remedy exists (as constitutional action) is wrong, it is correct in principle to assert that legal assistance goes to the availability of a judicial remedy for the purposes of Art. 5(2)(b) of the Optional Protocol.

The second point arises from the assertion. of a duty, on the courts of State Parties, to test the fairness of trial proceedings. ${ }^{31}$ While this duty, attributed to courts in the course of admissibility discussions, cannot in the view of the writer establish that a remedy has been exhausted, as suggested in Henry, the proposition is, taken by itself correct in principle and could be a useful factor in determining violations by State Parties of Article

Often, the Committee sets out counsel's argument, leaving it unclear whether or not it has been accepted by it, but creating a suspicion that it has so been. Collins provides yet again an example, and a near ludicrous one. Section 25 of the Jamaican Constitution which creates an action for redress of breach of fundamental right is side-noted 'Enforcement of protective provisions'. As one of these rights, is that to a fair trial, English counsel concluded (at para 3.11) that the only means of enforcing that right would be a re-trial, presumably a 'fair re-trial'. In Sawyers and McClean, it was argued no less absurdly that "as long as the Court of Appeal and the Privy Council conduct fair hearings, they provide adequate means of redress", and "the remedy under section 25 is not open to convicted persons" (at para. 10.2). Has the Committee endorsed these assertions?

Supra, note 16 and accompanying text. 
14.1. So that where a challenge to criminal proceedings, including the appeal proceedings is before the Committee, as raising a fair trial issue, the proposition could well go to establishing understanding of the nature of the obligation on states, created by Article 14.1 .

\section{B. Pratt and Morgan v. The Attorney-General of Jamaica}

The Constitutional motion brought by Morgan and Pratt, eventually found its way to the final court - the Privy Council, which gave judgment on November 2nd 1993, fourteen years and 11 months after the pronouncement of the death sentence.

The decision that execution after prolonged delay constituted inhuman and degrading treatment in breach of section 17 of the Constitution, involved the overturning of a line of cases culminating in Riley ${ }^{32}$, and the adoption of the dissent in the last named case. The Privy Council founded its judgment on "long hallowed practice in England and former British Colonies". It observed that the rules and practices in England and the colonies laid down a strict timetable for appeals to the Privy Council and provided that execution would only be stayed so long as the timetable was adhered to. ${ }^{33}$ These rules had been in force in Jamaica up to the date of its independence. Ironically then, the Judicial Committee based its decision on existing law and policy, which in principle was also the basis of the decision overturned by the case. ${ }^{34}$ Constitutional interpretation in and for the Commonwealth Caribbean still, it seems, cannot detach itself from existing law and practice, and Pratt and Morgan is not a decision as firmly rooted in principle as was the dissent adopted by it, from the Riley case.

Having asserted that the death row phenomenon must not become "part of our jurisprudence", the Privy Council had to adress the issue as to the length of time that could trigger unconstitutional delay, constituting inhuman and degrading treatment. Since, it was argued, it was in the nature of the human condition that a condemned person would take every opportunity to save his life through use of the appellate procedure, where such procedures, enabled the condemned person to prolong the hearings over a period of years, then the fault was to be attributed to the appellate system. As a consequence, the judgment indicates that the period spent on appeals, was not to be excluded. In proposing a two year period for the completion of domestic proceedings, the Privy Council expressly

Supra, note 12.

33

Supra, note 2 at $773 \mathrm{~J}$.

34

This was the result of two different issues being canvassed. Riley asked whether the punishment was lawful, whereas the case under discussion focused on the effect of delay. 
denied a purpose of laying down a rigid timetable - and asserted rather - a "reasonable target".

In examining appeals and forms of recourse open to a condemned person in Jamaica, the Privy Council had to take into account applications under the Optional Protocol, to the UNHR Com. (and the Inter-American Commission) as ones which could add to the time period between the sentence of death and the final date for execution. Their Lordships asserted that they wished to say nothing to discourage continued adherence 'to the bodies' concerned and expressly relied on the admissibility decision in Pratt and Morgan $v$. Jamaica (and in Carlton Reid), that a complainant before the Committee need not start constitutional proceedings, before making applications to that body. They therefore decided that such a complaint could be lodged immediately after a case had been disposed of by the Judicial Committee. In addition the non-appellate character of the Committee was emphasized.

The judicial ruminations then lead to the crucial proposition that "in any case in which execution is to take place more than five years after sentence there will be strong grounds for believing that the delay is such as to constitute 'inhuman or degrading punishment or other treatment'."

Returning to the matter of recourse to proceedings under the United Nations Covenant and Protocol, it must be noticed that while the UNHR Com.'s admissibility decision in Pratt and Morgan is correct on the issue to the effect of authoritative decisions of national courts on the exhaustion of local remedies, it was incorrect in its assertion that the criminal appeal was an alternative means of redress to the constitutional action, making it unnecessary to institute those proceedings before coming before the Committee.

Indeed, in a recent decision, Bradshaw v. Barbados ${ }^{35}$, the Committee declared inadmissible an application, in which constitutional proceedings had already begun and had been dismissed both at first instance and by the Barbados Court of Appeal and in which the final (constitutional) appeal is currently pending. Complete exhaustion of the constitutional redress action is therefore required unless it can be shown that these are being unreasonably delayed.

As a consequence of the above, the Privy Council's total 'five year limit' does not adequately take into account delays that will in fact occur as a result of the pursuit of model and nearly identical therewith. 
'international remedies' ${ }^{36}$ - and this is a difficulty even when it is considered that the five year period raises a presumption of, rather than establishes unconstitutional delay. The hurried execution in Trinidad and Tobago in July 1994 of a person sentenced to death within four days of the expiry of five years from sentence indicates that in practice five years will be taken by governments in the Commonwealth Caribbean as a fixed time in law, within which executions must be carried out to avoid unconstitutional delay.

The recurrence of references to retention of the death penalty and its consequences contain a clue as to the policy implications of the decision and the whole question of the death penalty. This in turn could produce two opposed states of affairs.

While the substantive decision in Pratt and Morgan may be seen as self-evident, the impact of the decision or process in capital cases and on criminal justice in general could be revolutionary. For unless the Executive and indeed the whole court and legal system now proceeds with unaccustomed expedition, capital punishment will de facto be abolished. At the same time, however, expedition may well now come, thus making executions more prevalent, where previously, vacillations as to the policy to be pursued on the death penalty issues, combined with delay in the appeal and other procedures caused persons to linger on death row, with little indication that they would ever be executed.

The case too may have a remoter and far-reaching consequence, namely the abolition of appeals - all appeals - to the Judicial Committee of the Privy Council and the creation of a Caribbean Court of Appeal, as a final court the the States of the Commonwealth Caribbean. Pratt and Morgan, viewed as a decision which gives 'comfort to murderers' and which may also be seen, however, dimly as not favouring the death penalty, in states in which that penalty has decided popular and in most cases governmental support could buttress calls, becoming more and more persistant for a final regional Court and the abolition of appeals seen as anachronistic and inconsistent with the status of independence. unrealistic. That period is that is generally taken to rule on the admissibility of the communication. 


\title{
The Constitution of Peru of 1993
}

\author{
By Jürgen Saligmann
}

After his "coup d'état from above" in April 1992, Peru's president Alberto Fujimori came under intense international pressure. He therefore caused a constituent assembly to be elected which produced a new constitution ratified by referendum at the end of 1993. On the basis of the 1979 constitution, itself the result of a non-democratic period of government, certain modifications were added whose impact on the political system of Peru cannot yet be precisely assessed.

The provisions on basic rights have not been fundamentally changed apart from the introduction of capital punishment for terrorist acts. Changes are of a largely peripheral nature, mainly adapting the law to existing circumstances. The same cannot be said of the provisions on the organisation of government where the possibility to re-elect an incumbent president was introduced and the bicameral parliament replaced by a unicameral congress. The relationship of the presidency and congress has likewise been remoulded, but time will have to tell whether this has strengthened the position of parliament.

\section{The Jamaican Constitution in Litigation of the Covenant on Civil and Political Rights - Repercussions and Resonances}

\section{By Margaret DeMerieux}

Jamaica is an adherent to the Optional Protocol to the International Covenant on Civil and Political Rights, which permits persons within its jurisdiction to bring individual complaints before the U.N. Human Rights Committee.

Proceedings before the Committee engage the Constitution in two ways. The international law requirement that domestic remedies be exhausted before recourse is had to international proceedings, requires the Committee to examine the Jamaican Constitution to determine compliance with this rule. Domestic remedies arise under the Constitution. This leads to the second point of 'interrelation' between domestic law and the Constitution and Covenant. The Constitution contains a Bill of Rights, which has its roots in the same family of instruments on human rights (and in particular the Universal Declaration) as the Covenant. As a result, provisions of the Bill of Rights bear a striking resemblance to those of the Covenant and especially Article 14 thereof constituting the right to fair trial. The interpretation of that Article by the Committee has implications therefore, for the interpretation of the analogous Bill of Rights provision in the domestic law. This is highlighted in the decision of Morgan and Pratt v. A.G. (Jamaica) as discussed in this article. 